Article

\title{
The Effects of Aluminium- and Ferric-Based Chemical Phosphorus Removal on Activated Sludge Digestibility and Dewaterability
}

\author{
Peter Ojo and Augustine Osamor Ifelebuegu *(D) \\ School of Energy, Construction and Environment, Coventry University, Coventry CV1 5FB, UK; \\ ojop@uni.coventry.ac.uk \\ * Correspondence: a.ifelebuegu@coventry.ac.uk; Tel.: +44-(0)2477657688
}

Received: 6 April 2019; Accepted: 19 April 2019; Published: 23 April 2019

check for updates

\begin{abstract}
The uses of $\mathrm{Al}^{3+}$ and $\mathrm{Fe}^{3+}$ salts in chemical phosphorus removal (CPR) in activated sludge plants have increased considerably in recent years and their full impacts on downstream processes such as dewaterability and digestibility are not fully understood. In this research, the effects of CPR on sludge digestibility and dewaterability were investigated in laboratory-scale experiments using sludge samples from a full-scale wastewater treatment plant. The results of the digestibility tests showed a $21 \%$ and $36 \%$ reduction in the biogas volume generated during anaerobic digestion of surplus activated sludge at $0.1 \mathrm{~g} / \mathrm{L}$ doses of $\mathrm{Al}^{3+}$ and $\mathrm{Fe}^{3+}$ salts, respectively. This demonstrates that $\mathrm{Al}^{3+}$ dosing for $\mathrm{CPR}$ has less of a reduction effect compared with $\mathrm{Fe}^{3+}$ salts on biogas generation during anaerobic digestion of sludge. The dewaterability tests showed that primary sludge dewaterability was improved by up to $25 \%$ by $\mathrm{Fe}^{3+}$ and $16 \%$ by $\mathrm{Al}^{3+}$, while that of surplus activated sludge was reduced by $64 \%$ and $73 \%$, respectively, at a metal salt dose of $50 \mathrm{mg} / \mathrm{L}$. Consequently, a pre-precipitation process during CPR where phosphorus is removed in the primary tank would, therefore, enhance sludge dewaterability.
\end{abstract}

Keywords: activated sludge; anaerobic digestion; biogas; metal salts; surplus activated sludge; capillary suction time

\section{Introduction}

The presence of nutrients, particularly phosphates, present a huge challenge in the treatment of wastewater both in municipal and industrial wastewater treatment plants (WWTPs). With the obligatory effluent discharge consent for phosphate removal becoming tighter under the EU Water Framework Directive, there is a growing demand for treatment plant upgrades to meet $\mathrm{P}$ consents in WWTP effluents. The activated sludge process (ASP) is the most widely used technique for municipal wastewater treatment and is able to achieve higher $P$ removal to levels of less than $1 \mathrm{mg} / \mathrm{L}$ [1]. The two main processes for phosphorus removal are biological phosphorus removal (BPR) and chemical phosphorus removal (CPR). Both processes are used independently and, most times, in combination to achieve effluent consents for P. While BPR is considered the most environmentally friendly option, it has its limitations, particularly, the requirement for strong biological oxygen demand (BOD) in the influent wastewater. Consequently, most WWTPs in Europe use CPR to achieve their effluent $P$ consents using mainly ferric $\left(\mathrm{Fe}^{3+}\right)$ and aluminium $\left(\mathrm{Al}^{3+}\right)$ salts for precipitation of phosphorus [2-4].

CPR has been reported to cause an increased volume of sludge between $37 \%$ and $97 \%$ [5]. Therefore, the CPR processes are to likely impact downstream processes due to the heavier load of metal salts used in the processes. The vital downstream processes include the anaerobic digestion (AD) and sludge dewatering processes [6]. The former is a well-known technology that biologically treats and degrades organic substrates in the absence of oxygen, the impact of which has been progressively increasing over 
the last decade $[7,8]$, while the latter is known to reduce the sludge volume by separating the water from the activated sludge (AS) solids [9]. The addition of coagulants $\left(\mathrm{Al}^{3+}\right.$ and $\left.\mathrm{Fe}^{3+}\right)$ can adversely impact the $\mathrm{AD}$ process and the dewaterability of the resultant sludges due to increased sludge production. Sludge treatment and disposal accounts for nearly $60 \%$ of the entire running cost of WWTPs [10] and, therefore, need to be further understood for the purpose of process optimisation and cost savings.

There have been various reports on the use of metal salts for the conditioning of sludge and their effects on sludge treatment processes [7-11]. Also, previous studies by Smith and Carliell-Marquet [12,13] have reported on the digestibility of Fe-dosed sludge, with a reduced biogas production rate as a result of Fe dosing. Research on the effects of $\mathrm{Al}^{3+}$ salt on the digestibility of activated sludge is limited in the literature. This study provides a comparative assessment of the effects of $\mathrm{Fe}^{3+}$ and $\mathrm{Al}^{3+}$ on the digestibility of surplus activated sludge (SAS).

Several factors have been reported to affect the dewaterability of activated sludge, including surface chemistry (zeta potential) [14]; yield stress, which explains the sludge rheological characteristics [15]; bound water content [16] and extracellular polymeric substances (EPS) content [17]. Several chemicals have been researched as conditioners for the improvement of sludge dewaterability including chemical coagulants such as aluminium sulphate, ferric chloride, calcium hydroxide, polyelectrolyte, surfactants and enzymes [18], acids and surfactants [19], Fenton's reagent pretreatment [20], calcined aluminium salt and potassium ferrate [21]. While most of these studies focused on the effects of the use of these conditioners when used for conditioning during sludge treatment processes, there has been limited research on the effects of the chemicals used in the upstream activated sludge process for the precipitation of phosphorus on the downstream dewatering process. The second objective of this paper is to investigate the effects of CPR on the dewaterability of WWTP primary sludge and SAS.

\section{Materials and Methods}

\subsection{Activated Sludge Digestibility and Dewaterability Sampling}

Activated sludge samples were collected in three sampling campaigns between 2016 and 2017 from a WWTP in the West Midlands in the United Kingdom. The WWTP is an activated sludge plant with an average design flow of $450,000 \mathrm{~m}^{3} / \mathrm{d}$ at full flow to treatment (FFT) of 1,070,000 $\mathrm{m}^{3} / \mathrm{d}$. The WWTP was chemically dosed at the end of the ASP and samples were collected upstream of the chemical dosing point. The SAS samples were collected in 32.5-L plastic containers from the distribution chambers and transferred to the laboratory-scale plant. The mixed liquor suspended solids (MLSS) concentration of the samples ranged from 2800 to $3500 \mathrm{mg} / \mathrm{L}$, with the $\mathrm{pH}$ ranging from 6.5 to 7.5 and a phosphate concentration of $7-12 \mathrm{mg} / \mathrm{L}$. All chemicals including aluminium sulphate and ferric chloride used were of analytical grade and purchased from Sigma Aldrich (Gillingham, UK). All experiments were commenced within $24 \mathrm{~h}$ of sampling, as findings have shown that longer storage times reduce biogas generation due to the degradability of the readily biodegradable carbon [12]. $\mathrm{Al}^{3+}$ and $\mathrm{Fe}^{3+}$ were used for the CPR process.

\subsection{Digestibility Tests}

Two quantities of 2-L flat round-bottom flasks were used as the laboratory digester for both the $\mathrm{Fe}^{3+}$ - and $\mathrm{Al}^{3+}$-dosed samples alongside their respective controls. The two bioreactors (digesters) containing the SAS were made up of one as the test (chemical-dosed sludge) and the other as the control (Figure 1). As a control, $1500 \mathrm{~mL}$ of SAS was measured without chemical and transferred into the first flat round-bottom flask. To give it some organic carbon, $20.5 \mathrm{~g}$ of sucrose was added, which facilitated readily degradable carbon, and a magnetic stirrer was used to give it slow stirring to promote uniformity of the sample in the digesters. From the anaerobic sludge tank, $40 \mathrm{~g}$ of sludge was used for bioaugmentation to enhance and speed up the microbial activities. They were also flushed with nitrogen gas to ensure anaerobic conditions. The second flat round-bottom flask containing the same sample was then pretreated with $200 \mathrm{~mL}$ of $100 \mathrm{mg} / \mathrm{L}$ as $\mathrm{Fe}^{3+}$ solution. The experiments were also 
repeated with $100 \mathrm{mg} / \mathrm{L}$ as $\mathrm{Al}^{3+}$ solution. Initial jar tests showed that phosphorus levels were reduced to $<0.5 \mathrm{mg} / \mathrm{L}$ between 50 and $100 \mathrm{mg} / \mathrm{L}$ doses of the metal salts. The maximum dose of $100 \mathrm{mg} / \mathrm{L}$ was then chosen for the digestion experiments. The test and control sludge samples were digested at mesophilic temperatures $\left(35^{\circ} \mathrm{C}\right)$ for 12 days until the biogas production subsided. The temperature of digestion was maintained at $35^{\circ} \mathrm{C}$ throughout the experiment as most mesophiles grow best within the temperature range of $30-35^{\circ} \mathrm{C}$ [22]. The experiments were repeated twice, and average data are reported. The digestibility of the test and control sludge was evaluated by measuring the biogas volume using a manometer (Dwyer flex-tube series 1222 U-tube manometer containing red gauge fluid, Michigan, USA).

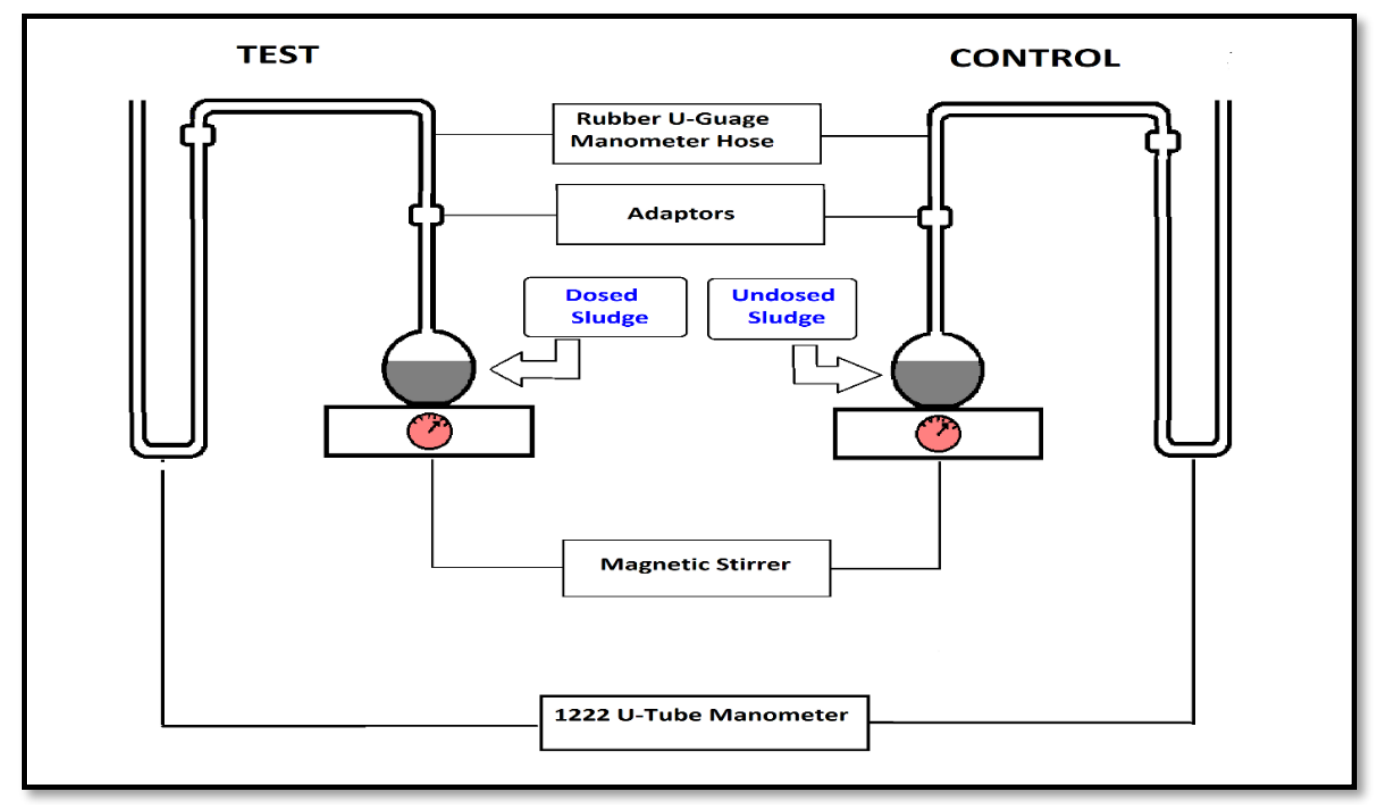

Figure 1. Anaerobic digester setup for test and control samples.

\subsection{Dewaterability Tests}

For the dewaterability tests, a set of three laboratory-batch-scale experiments were carried out in $1000-\mathrm{mL}$ beakers with a sludge sample of $500 \mathrm{~mL}$. $\mathrm{Al}^{3+}$ and $\mathrm{Fe}^{3+}$ salts at volumes of $0,10,20,25$ and 50 $\mathrm{mL}$ were added to each beaker containing $500 \mathrm{~mL}$ of sludge. The homogeneity of the sludge mixture was ensured throughout the reaction by stirring at $2 \mathrm{rpm}$ using an overhead stirrer. Then, $25 \mathrm{~mL}$ of the control and $\mathrm{Al}^{3+}$ - and $\mathrm{Fe}^{3+}$-dosed samples $(10,20,40,50$ and $100 \mathrm{mg} / \mathrm{L}$ ) were collected and analysed using a standard Triton UK-Type 304B capillary suction time (CST) device (Essex, UK) [23], equipped with an 18-mm reservoir resting on standard Whatman No. 17 grade chromatography paper. The dewaterability of the sludge was monitored using the CST dewaterability parameter. Three replicates of each dewaterability condition were performed with the samples analysed in triplicates to ensure the reproducibility of the experimental test results, and the mean values of CST were then recorded and reported. The details of the experimental procedures have been previously described in detail by Scholz [24] and Sawalha and Scholz [25]. All the test results reported are the means and standard deviation of three independent samples

The effects of the metal salts $\left(\mathrm{Al}^{3+}\right.$ and $\mathrm{Fe}^{3+}$ ) were evaluated using Equation (1) for reduction percentage $(\%)$ of CST:

$$
R \%=\frac{\left(C S T_{0}-C S T_{d}\right)}{\left(C S T_{0}\right)} \times 100 \%
$$

where $C S T_{0}$ is the initial sludge CST, and $\operatorname{CST}_{d}$ is the sludge CST after chemical dosing. 


\section{Results and Discussion}

\subsection{Effects of Aluminium and Ferric Dosing on Biogas Production}

The sludge digestibility was investigated in a laboratory-scale anaerobic digester (Figure 1). All the test results reported in Table 1 and Figure 2 are the means and standard deviation of three independent samples. The results of the digestibility test showed that the mean cumulative biogas volumes produced for the undosed digested sludges after the first sludge age (12 days) were $31.56 \pm$ 2.3 and $34.91 \pm 1.3 \mathrm{~mL}$, compared with the $\mathrm{Al}^{3+}$-dosed sludge of $24.85 \pm 1.3 \mathrm{~mL}$ and $\mathrm{Fe}^{3+}$-dosed sludge of $22.46 \pm 1.5 \mathrm{~mL}$, respectively. This indicates a $21.3 \%$ and $35.7 \%$ reduction in the biogas volume as a result of CPR using $100 \mathrm{mg} / \mathrm{L}$ of $\mathrm{Al}^{3+}$ and $\mathrm{Fe}^{3+}$, respectively.

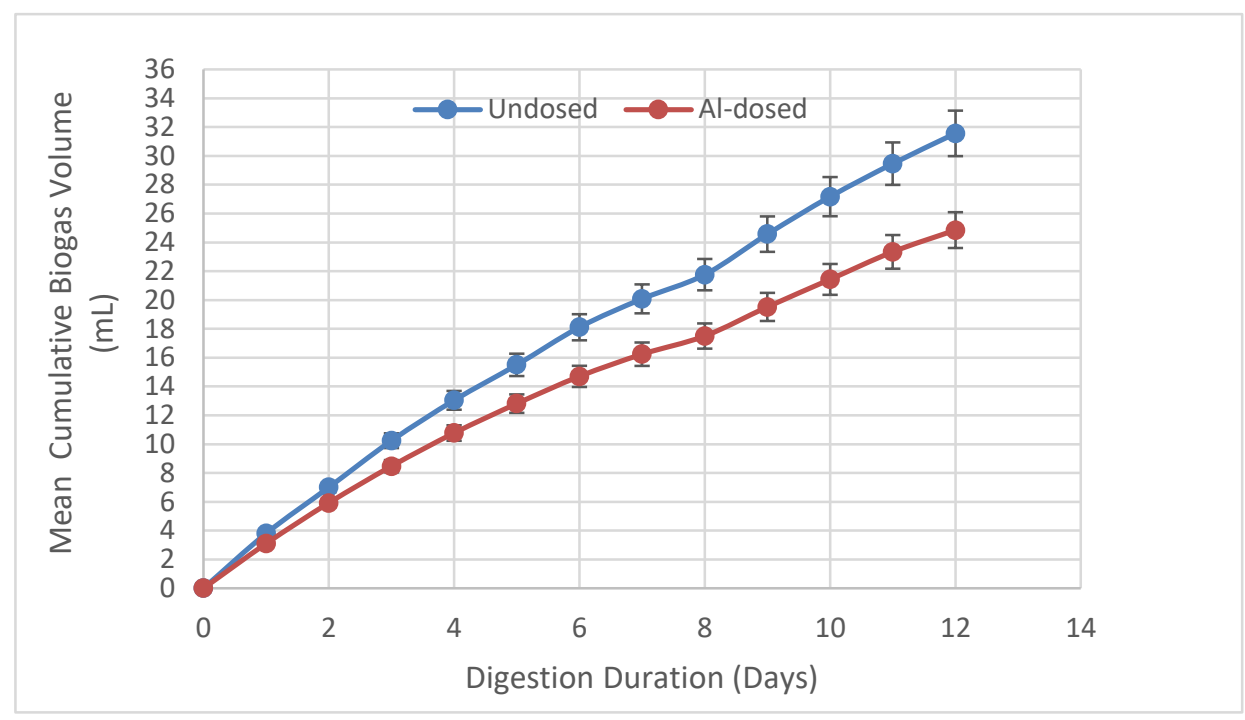

(a)

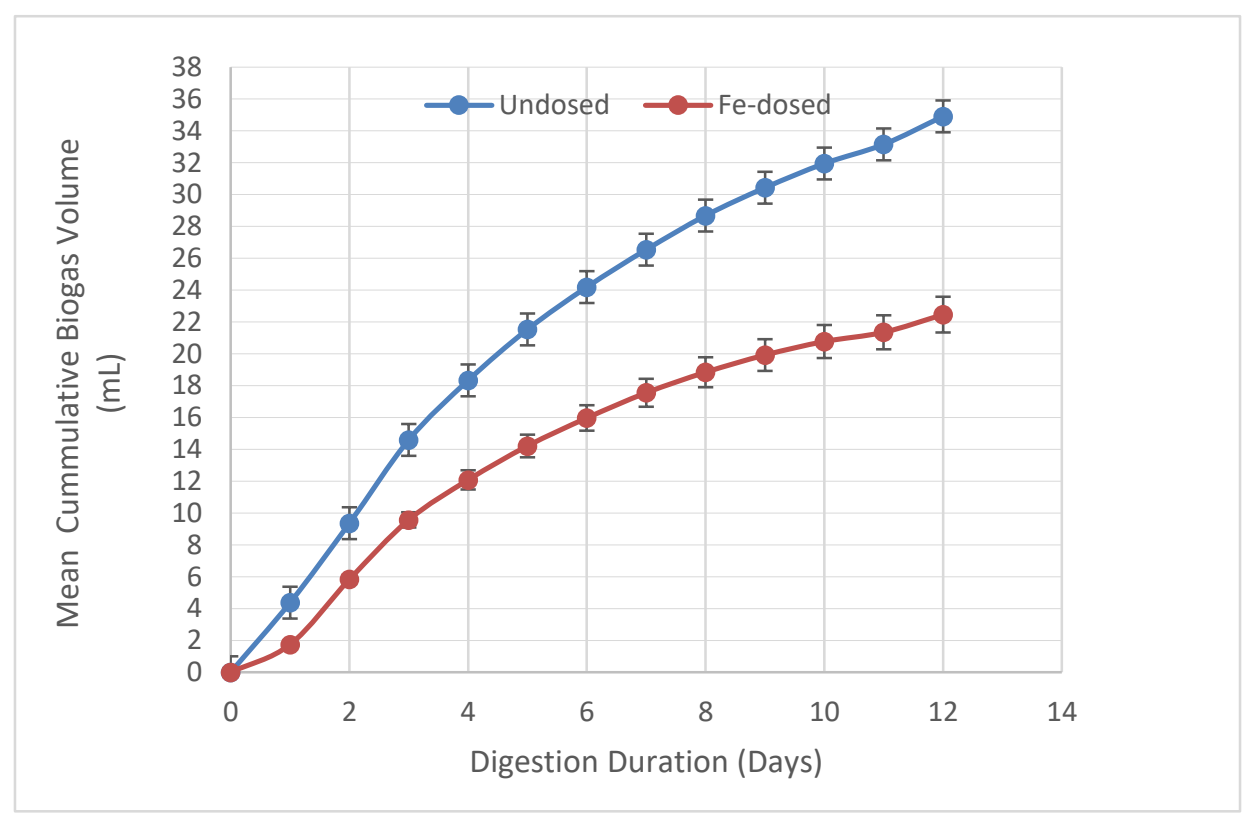

(b)

Figure 2. The effects of metal salt dosing for chemical phosphorus removal (CPR) on the cumulative biogas generation in an anaerobic digester. (a) $\mathrm{Al}^{3+}$-dosed surplus activated sludge (SAS) and (b) $\mathrm{Fe}^{3+}$-dosed SAS. Error bars represent the standard deviation (SD) of three independent replicates. 
Table 1. Cumulative biogas volume production after 12 days.

\begin{tabular}{ccc}
\hline & Fe $^{3+}$-Dosed SAS (Control) & Al $^{3+}$-Dosed SAS (Control) \\
\hline Cumulative biogas $(\mathrm{mL})$ after 12 days & $22.46 \pm 1.5(34.91 \pm 1.3)$ & $24.85 \pm 1.3(31.56 \pm 2.3)$ \\
$\%$ Biogas reduction & $35.7 \%$ & $21.3 \%$ \\
\hline
\end{tabular}

Reduced biogas production as a result of chemical phosphorus removal using ferric has been previously reported [13]. Biogas reductions of 20\% [26,27], 21\%-32\% [28] and 32\% [29] were previously reported for mixed sludges. The current study showed a $19.65 \%$ and $35.16 \%$ reduction in the biogas volumes after CPR treatment with $100 \mathrm{mg} / \mathrm{L}$ of $\mathrm{Al}^{3+}$ and $\mathrm{Fe}^{3+}$ salts, respectively. This is in agreement with the range of $20 \%-50 \%$ reduction previously reported by Ofverstrom et al. [30]. Although the previous studies were on mixed sludge, the current research provides data on SAS and compares the biogas reduction effects of alum and ferric salts. There was a clear indication that between the $\mathrm{Al}^{3+}-$ and $\mathrm{Fe}^{3+}$-digested sludge, $\mathrm{Fe}^{3+}$ caused an estimated $15.51 \%$ further reduction in biogas production compared with $\mathrm{Al}^{3+}$. Therefore, for the purpose of $\mathrm{CPR}, \mathrm{Al}^{3+}$-dosed sludge yields about $15.51 \%$ more gas than $\mathrm{Fe}^{3+}$-dosed activated sludge.

The reason for this high rate of biogas production in undosed sludge compared with the metal $\left(\mathrm{Al}^{3+}\right.$ and $\left.\mathrm{Fe}^{3+}\right)$-dosed sludges may be attributed to the increased availability of the substrate for metabolism and possibly due to the microbial community in the seeded sludge being more susceptible to breaking down undosed SAS compared with aluminium- and ferric-dosed SAS. The reduced biogas production for the $\mathrm{Al}^{3+}$ - and $\mathrm{Fe}^{3+}$-dosed sludges can also be due to the substrates, such as proteins, that form the majority of the components in the sludge (SAS) being tightly bound to the surface of the $\mathrm{Al}^{3+}$-dosed sludge precipitate and $\mathrm{Fe}^{3+}$-dosed sludge being entangled within the sludge floc [28]. It has been suggested that the reduction in biogas volume of $\mathrm{Al}^{3+}$-dosed sludge compared with undosed sludge may be due to the time length of producing and hydrolysing the substrate [31]. Further, the strong bond of proteins to aluminium may cause a reduction in the rate of biogas production [31]. It has also been inferred that the biogas reduction may be attributed to the reduced availability of microbial population to organics $[26,28]$.

\subsection{Effects of Aluminium and Ferric Dosing on Sludge Dewaterability}

CST is the most widely used dewaterability parameter for monitoring sludge dewaterability. The CST test estimates the filtration rate in terms of time for free water to pass between two electrodes using a filter paper as the medium [32]. Longer CST indicates poor sludge dewaterability, while shorter CST indicates good sludge dewaterability $[9,33]$. The results of the sludge dewaterability (mean CST) for $\mathrm{Al}^{3+}$ - and $\mathrm{Fe}^{3+}$-dosed primary sludge and secondary sludge at concentrations of 0 , $20,30,40$ and $50 \mathrm{mg} / \mathrm{L}$ for the batch tests (1 and 2) using an 18-mm reservoir are summarised in Tables 2 and 3. All test results reported in Tables 2 and 3 are the means and standard deviation of three independent primary and secondary sludge samples. It was observed that the mean CST reduced with the increasing concentration of $\mathrm{Al}^{3+}$ and $\mathrm{Fe}^{3+}$ doses $(20,30,40$ and $50 \mathrm{mg} / \mathrm{L})$ in primary sludge, while mean CST increased with the increasing concentration of $\mathrm{Al}^{3+}$ and $\mathrm{Fe}^{3+}$ doses $(20,30,40$ and $50 \mathrm{mg} / \mathrm{L}$ ) in secondary sludge. Shorter CST indicates good dewaterability, while longer CST signifies poor dewaterability $[10,27]$.

The chemically dosed primary sludges showed reduced CST (better dewaterability) compared with the undosed sludge. The CST decreased with increasing doses of $\mathrm{Al}^{3+}$ and $\mathrm{Fe}^{3+}$. As can be seen in Table 2, there was a $25.1 \%$ and $16.2 \%$ improvement in the rate of dewaterability of primary sludge at $50 \mathrm{mg} / \mathrm{L} \mathrm{CPR}$ doses of $\mathrm{Al}^{3+}$ and $\mathrm{Fe}^{3+}$ salts, respectively. This indicates that $\mathrm{CPR}$, by a pre-precipitation method where phosphorus is precipitated out in the primary sedimentation tank, would be more beneficial for enhancing sludge dewaterability. The observed CST reduction for the primary sludge following the CPR may be due to the ability of multivalent coagulants ( $\mathrm{Al}^{3+}$ and $\mathrm{Fe}^{3+}$ salts) to interact with the microbial clusters and break the EPS structure bound with water [34]. This could also be 
due to the neutralisation of the negative charge on the sludge floc since the EPS is negatively charged and responsible for an increased surface charge (zeta potential) of microbial aggregates which causes decreased settleability and flocculability of microbial clusters [35].

Table 2. Mean and standard deviation data of capillary suction time (CST) and CST reduction efficiency for undosed and dosed primary sludges.

\begin{tabular}{ccccc}
\hline \multirow{2}{*}{$\begin{array}{c}\text { Coagulant } \\
\text { Concentration }(\mathbf{m g} / \mathbf{L})\end{array}$} & \multicolumn{2}{c}{ CST (s) } & \multicolumn{2}{c}{ \% CST Reduction } \\
\cline { 2 - 5 } & $\mathbf{F e}^{\mathbf{3 +}}$ & $\mathbf{A l}^{\mathbf{3 +}}$ & $\mathbf{F e}^{\mathbf{3 +}}$ & $\mathbf{A l}^{\mathbf{3 +}}$ \\
\hline 0 & $18.0 \pm 3.04$ & $18.0 \pm 3.04$ & - & - \\
20 & $16.26 \pm 2.22$ & $16.83 \pm 3.95$ & 9.67 & 6.50 \\
30 & $15.29 \pm 1.77$ & $16.24 \pm 4.54$ & 15.10 & 9.75 \\
40 & $14.39 \pm 1.84$ & $15.66 \pm 5.18$ & 20.10 & 13.00 \\
50 & $13.49 \pm 2.18$ & $15.07 \pm 5.86$ & 25.10 & 16.25 \\
\hline
\end{tabular}

Table 3. Mean and standard deviation data of CST for undosed and dosed sludge surplus activated sludges.

\begin{tabular}{ccccc}
\hline \multirow{2}{*}{$\begin{array}{c}\text { Coagulant } \\
\text { Concentration }(\mathbf{m g} / \mathbf{L})\end{array}$} & \multicolumn{2}{c}{$\mathbf{C S T}(\mathbf{s})$} & \multicolumn{2}{c}{$\%$ CST Increase } \\
\cline { 2 - 5 } & $\mathbf{F e}^{3+}$ & $\mathbf{A l}^{3+}$ & $\mathbf{F e}^{3+}$ & $\mathbf{A l}^{3+}$ \\
\hline 0 & $33.17 \pm 2.04$ & $33.17 \pm 2.04$ & - & - \\
20 & $43.7 \pm 1.76$ & $47.97 \pm 1.37$ & 31.75 & 44.62 \\
30 & $47.91 \pm 2.77$ & $52.49 \pm 0.71$ & 44.46 & 58.26 \\
40 & $51.23 \pm 4.87$ & $55.57 \pm 2.56$ & 54.47 & 67.54 \\
50 & $54.33 \pm 4.87$ & $57.37 \pm 5.60$ & 63.82 & 72.96 \\
\hline
\end{tabular}

However, the neutralisation effect of increasing chemical dosing $\left(\mathrm{Al}^{3+}\right.$ and $\left.\mathrm{Fe}^{3+}\right)$ on the primary sludge will improve dewaterability with a shorter CST value. This is due to reduced repulsive forces between the sludge flocs and release of bound water to the sludge floc matrix [36]. It was mentioned that surface charge chemistry and disruption of the EPS structure are responsible for shorter CST $[37,38]$. The observed shorter CST reported in the primary sludge could also be due to polymer bridging [39] resulting in the destabilisation of colloidal particles present in sludge floc. Therefore, in the current study, it can be concluded that the reduced CST, as a function of the impact of chemical dosing on the primary sludge, improved dewaterability due to the surface charge chemistry and disruption of the sturdy EPS structure bound with water.

In contrast, the results of the sludge dewaterability (mean CST) for $\mathrm{Al}^{3+}$ - and $\mathrm{Fe}^{3+}$-dosed secondary sludge (SAS) at a concentration of $0,20,30,40$ and $50 \mathrm{mg} / \mathrm{L}$ using an 18-mm reservoir are presented in Table 3. From the results, it was observed that the mean CST increased with the increasing concentration of aluminium and ferric $(20,30,40$ and $50 \mathrm{mg} / \mathrm{L})$. At $50 \mathrm{mg} / \mathrm{L}$ of $\mathrm{Al}^{3+}$ and $\mathrm{Fe}^{3+} \mathrm{CPR}$ doses, $72.96 \%$ and $63.82 \%$ reductions in SAS dewaterability (increased CST values) were respectively observed, indicating that if CPR is applied by coprecipitation in activated sludge plants using these salts, there will be a significant reduction in the dewaterability rates of the resultant SAS. The observed behaviour may be due to the interaction between the multivalent coagulants $\left(\mathrm{Al}^{3+}\right.$ and $\left.\mathrm{Fe}^{3+}\right)$ and higher EPS content, which has a tendency to limit the flocculating and settleability ability of microbial clusters. This limitation will further cause the water retention capacity and quantity of bound water in the EPS to rise and, hence, restricts the outflow of interstitial water from the sludge floc pore spaces [19,40]. Another probable reason may be due to the reduction and solubility of coagulants $\left(\mathrm{Al}^{3+}\right.$ and $\mathrm{Fe}^{3+}$ ), causing protein to enter into the solution and a fragile connection between the protein structure and the sludge floc, which may limit dewaterability improvement [41]. Also, it may be due to increased resistance and binding from the sludge floc [42]. 


\section{Conclusions}

The effects of chemical phosphorus removal using $\mathrm{Al}^{3+}$ and $\mathrm{Fe}^{3+}$ salts on activated sludge digestibility in batch settling tests using a locally designed laboratory anaerobic digester and activated sludge dewaterability using a new CST type 304B suction device were investigated. The results demonstrated that the use of $\mathrm{Al}^{3+}$ and $\mathrm{Fe}^{3+}$ salts reduced the digestibility of surplus activated sludge, with $\mathrm{Al}^{3+}$ salt having up to $15 \%$ less reduction effect compared with $\mathrm{Fe}^{3+}$. Also, $\mathrm{Al}^{3+}$ and $\mathrm{Fe}^{3+}$ salts improved the dewaterability of primary sludge by $16 \%$ and $25 \%$ but significantly reduced the dewaterability of SAS by $73 \%$ and $64 \%$, respectively. The results demonstrated that using $\mathrm{Al}^{3+}$ and $\mathrm{Fe}^{3+}$ salts in the CPR process will improve the dewaterability of primary sludge but decrease the dewaterability of SAS. It can therefore be inferred that for the purpose of optimising the dewaterability of activated sludge, a pre-precipitation process where phosphorus is removed in the primary tank would be more ideal during the CPR process.

Author Contributions: A.O.I. conceived the experiment; P.O. and A.O.I. designed and conducted the experiments and data analysis; A.O.I. and P.O. wrote the paper.

Funding: This project was support by BES Seeding funding Coventry University, UK.

Acknowledgments: The authors wish to thank Severn Trent Water, UK for their support and assistance during the periods of sampling.

Conflicts of Interest: The authors declare no conflict of interest.

\section{References}

1. Ojo, P.; Ifelebuegu, A.O. The Impact of Aluminium Salt for Chemical Phosphorus Removal on the Settleability of Activated Sludge. Environments 2018, 5, 88. [CrossRef]

2. Ojo, P.; Ifelebuegu, A.O. The Impact of Alum on the Bulking of a Full Scale Activated Sludge Plant. Environ. Eng. 2016, 3, 6-10.

3. Ojo, P.; Ifelebuegu, A.O. Effect of Aluminium Salt Dosing on Activated Sludge Settleability Indicators: A New Settleability Model Development. Water 2019, 11, 179. [CrossRef]

4. Wilfert, P.; Kumar, P.S.; Korving, L.; Witkamp, G.J.; van Loosdrecht, M.C.M. The relevance of phosphorus and iron chemistry to the recovery of phosphorus. Environ. Sci. Technol. 2015, 49, 9400-9414. [CrossRef]

5. Yeoman, S.; Stephenson, T.; Lester, J.N.; Perry, R. The removal of phosphorus during wastewater treatment: a review. Environ. Pollut. 1988, 49, 183-233. [CrossRef]

6. Sawatdeenarunat, C.; Surendra, K.C.; Takara, D.; Oechsner, H.; Khanal, S.K. Anaerobic digestion of lignocellulosic biomass: Challenges and opportunities. Bioresour. Technol. 2015, 78, 178-186. [CrossRef]

7. Zhang, Q.; Hu, J.; Jahng, D. Biogas from anaerobic digestion processes: Research updates. Renew. Energy 2016, 98, 108-119. [CrossRef]

8. Romero-Güiza, M.S.; Vila, J.; Mata-Alvarez, J.; Chimenos, J.M.; Astals, S. The role of additives on anaerobic digestion: A review. Renew. Sustain. Energy Rev. 2016, 58, 1486-1499. [CrossRef]

9. Niu, M.; Zhang, W.; Wanga, D.; Chen, Y.; Chen, R. Correlation of physicochemical properties and sludge dewaterability under chemical conditioning using inorganic coagulants. Bioresour. Technol. 2013, 144, 337-343. [CrossRef]

10. Zhou, X.; Wang, Q.; Jiang, G.; Zhang, X.; Yuan, Z. Improving dewaterability of waste activated sludge by combined conditioning with zero-valent iron and hydrogen peroxide. Bioresour. Technol. 2014, 174, 103-107. [CrossRef]

11. Haandel, A.C.V.; Lubbe, J.G.M.V. Handbook of Biological Wastewater Treatment: Design and Optimisation of Activated Sludge System, 2nd ed.; IWA Publishing: London, UK, 2012.

12. Smith, J.A.; Carliell-Marquet, C.M. The digestibility of iron-dosed activated sludge. Bioresour. Technol. 2008, 99, 8585-8592. [CrossRef]

13. Smith, J.A.; Carliell-Marquet, C.M. A novel laboratory method to determine the biogas potential of iron-dosed activated sludge. Bioresour. Technol. 2009, 100, 1767-1774. [CrossRef]

14. Lee, C.H.; Liu, J.C. Enhanced sludge dewatering by dual polyelectrolytes conditioning. Water Res. 2000, 34, 4430-4436. [CrossRef] 
15. Lotito, V.; Spinosa, L.; Mininni, G.; Antonacci, R. The rheology of sewage sludge at different steps of treatment. Water Sci. Technol. 1997, 36, 79-85. [CrossRef]

16. Keiding, K.; Wybrandt, L.; Nielson, P.H. Remember the water: Comment on EPS colligative properties. Water Sci. Technol. 2001, 43, 17-23. [CrossRef]

17. Mowla, D.; Tran, H.N.; Allen, G.D. A Review of the properties of biosludge and its relevance to enhanced dewatering processes. Biomass Bioenergy 2013, 58, 365-378. [CrossRef]

18. Ruiz-Hernando, M.; Martinez-Elorza, G.; Labanda, J.; Llorens, J. Dewaterability of sewage sludge by ultrasonic, thermal and chemical treatments. Chem. Eng. 2013, 230, 102-110. [CrossRef]

19. Chen, Y.G.; Yang, H.Z.; Gu, G.W. Effect of acid and surfactant treatment on activated sludge dewatering and settling. Water Res. 2001, 35, 2615-2620. [CrossRef]

20. Tony, M.A.; Zhao, Y.Q.; Fu, J.F.; Tayeb, M. Conditioning of aluminum-based water treatment sludge with Fenton's reagent: Effectiveness and optimising study to improve dewaterability. Chemosphere 2008, 72, 673-677. [CrossRef]

21. Ye, F.; Liu, X.; Li, Y. Effects of potassium ferrate on extracellular polymeric substances (EPS) and physicochemical properties of excess activated sludge. J. Hazard. Mater. 2012, 199-200, 158-163. [CrossRef]

22. Gerardi, M.H. The Microbiology of Anaerobic Digesters; Wiley-Interscience: Hoboken, NJ, USA, 2003; pp. 51-57.

23. Triton Ltd. 2017 Type 304 B CST Device. Available online: http://www.tritonel.com/product/type-304-cst/ (accessed on 8 May 2016).

24. Scholz, M. Review of recent trends in capillary suction time CST dewaterability testing research. Ind. Eng. Chem. Res. 2005, 44, 8157-8163. [CrossRef]

25. Sawalha, O.; Scholz, M. Assessment of capillary suction time (CST) test methodologies. Environ. Technol. 2007, 28, 1377-1386. [CrossRef]

26. Kindzierski, W.; Hrudey, S. Effects of phosphorus removal chemicals upon methane production during anaerobic sludge digestion. Can. Civ. Eng. 1986, 13, 33-38. [CrossRef]

27. Yeoman, S.; Lester, J.; Perry, R. The effects of chemical phosphorus precipitation on anaerobic digestion. Environ. Technol. 1990, 11, 709-720. [CrossRef]

28. Dentel, S.K.; Gosset, J.M. Effect of chemical coagulation on anaerobic digestibility of organic materials. Water Res. 1982, 16, 707-718. [CrossRef]

29. Johnson, D.K.; Carliell-Marquet, C.M.; Forster, C.F. An examination of the treatment of iron-dosed waste activated sludge by anaerobic digestion. Environ. Technol. 2003, 24, 937-945. [CrossRef]

30. Ofverstrom, S.; Sapkaite, I.; Dauknys, R. An investigation of impact of iron and aluminium addition on the anaerobic digestion process. In Proceedings of the Linnaeus Eco-Tech 10, Kalmar, Sweden, 22-24 November 2010.

31. Park, C.; Muller, C.D.; Abu-Orf, M.M.; Novak, J.T. The effect of wastewater cations on activated sludge characteristics: Effects of aluminium and iron in floc. Water Environ. Res. 2006, 78, 31-40. [CrossRef]

32. Sawalha, O.; Scholz, M. Modeling the relationship between capillary suction time and specific resistance to filtration. J. Environ. Eng. 2010, 136, 983-991. [CrossRef]

33. Feng, X.; Deng, J.; Lei, H.; Bai, T.; Fan, Q.; Li, Z. Dewatering of waste activated sludge with ultrasonic conditioning. Bioresour Technol. 2009, 100, 1074-1081. [CrossRef] [PubMed]

34. Laspidou, C.S.; Rittmann, B.E. A unified theory for extracellular polymeric substances, soluble microbial products, and active and inert biomass. Water Resour. 2002, 36, 2711-2720. [CrossRef]

35. Liu, X.M.; Sheng, G.P.; Yu, H.Q.; Luo, H.W.; Zhang, F.; Yuan, S.J. Contribution of extracellular polymeric substances (EPS) to the sludge aggregation. Environ. Sci. Technol. 2010, 44, 4355-4360. [CrossRef]

36. Vaxelaire, J.; Cezac, P. Moisture distribution in activated sludges: A review. Water Res. 2004, 38, $2215-2230$. [CrossRef] [PubMed]

37. Li, C.W.; Lin, J.L.; Kang, S.F.; Liang, C.L. Acidification and alkalization of textile chemical sludge: Volume/solid reduction, dewaterability, and Al (III) recovery. Sep. Purif. Technol. 2005, 42, 31-37. [CrossRef]

38. Dursun, D.; Turkmen, M.; Abu-Orf, M.; Dental, S.K. Enhanced sludge conditioning by enzyme pre-treatment: Comparison of laboratory and pilot scale dewatering results. Water Sci. Technol. 2006, 54, 33-41. [CrossRef]

39. Higgins, M.J.; Chen, Y.; Murthy, S.N. Understanding Factors Affecting Polymer Demand for Conditioning and Dewatering; IWA Publishing: London, UK, 2006; ISBN 1-84339-726-9.

40. Houghton, J.; Quarmby, J.; Stephenson, T. Municipal wastewater sludge dewatering and the presence of microbial extracellular polymer. Water Sci. Technol. 2001, 44, 373-379. [CrossRef] 
41. Novak, J.T.; Muller, C.D.; Murthy, S.N. Floc structure and the role of cations. Water Sci. Technol. 2001, 44, 209-213. [CrossRef]

42. Neyens, E.; Baeyens, J. A review of thermal sludge pre-treatment processes to improve dewaterability. J. Hazard. Mater. 2003, 98, 51-67. [CrossRef] 